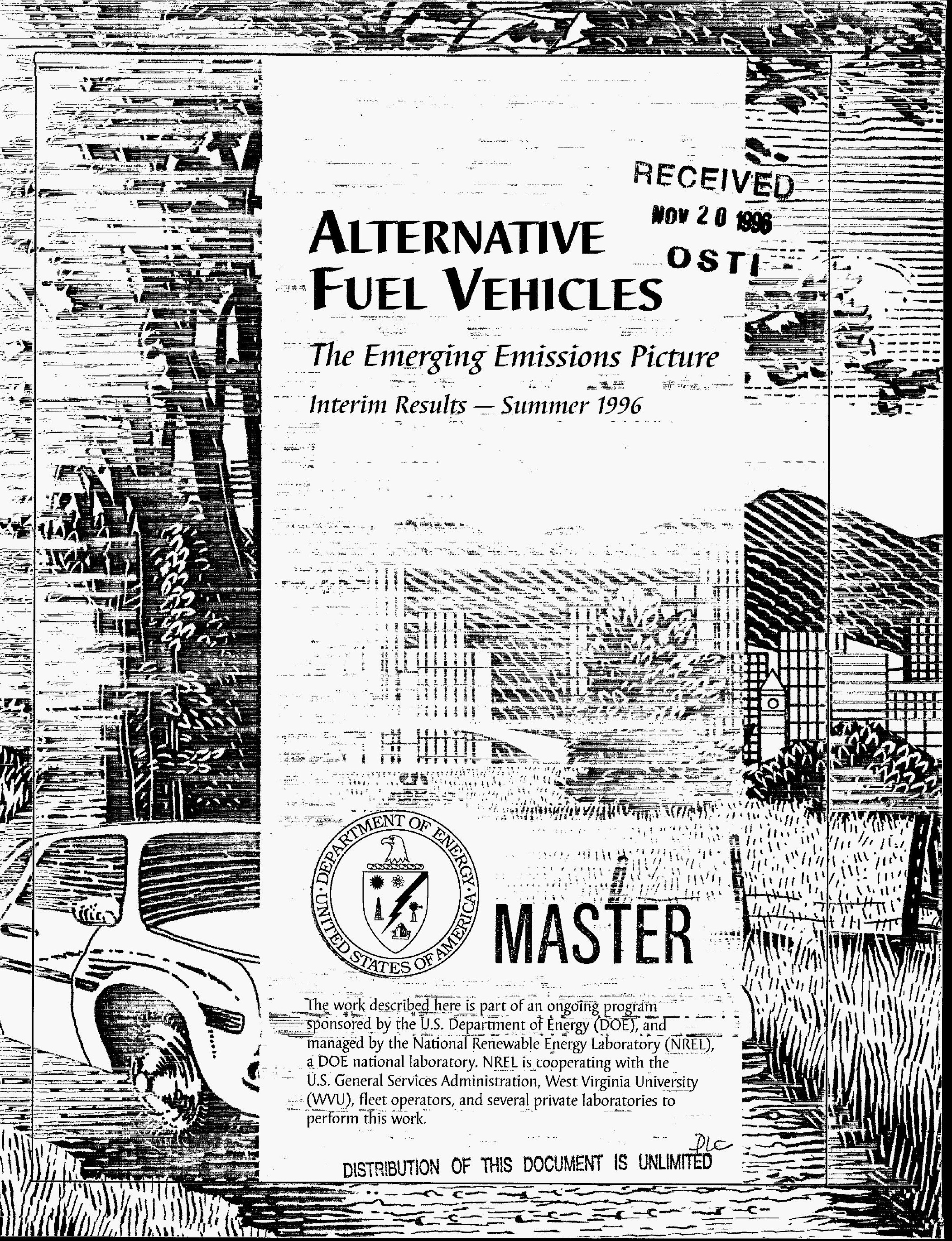




\section{Program Goal:}

To provide a high-quality, objective evaluation of in-use emissions from commercially available alternative fuel vehicles.

\section{Program Description}

Vehicles from the U.S. Federal fleet are randomly selected and delivered to private emissions test facilities in this statistically designed program. The testing is performed on a chassis dynamometer according to Federal Test Procedures for emissions certification. These procedures include exhaust and evaporative emissions. Additional detail is obtained by performing hydrocarbon speciation on the emissions.

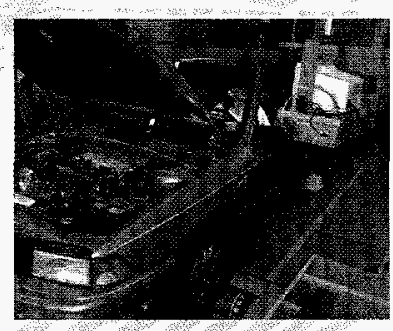

On a chassis dynamometer, the wheels of a test vehicle are supported by rollers that simulate driving conditions, while the driver follows a test cycle. Laboratory instruments measure fuel economy and regulated emissions.

Hydrocarbon speciation is the most comprehensive type of analysis run on

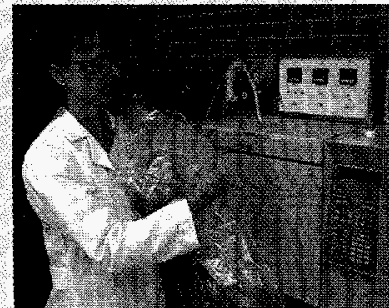
emissions. In this analysis, hundreds of hydrocarbon compounds found in vehicle emissions are quantified. These results are used to study the toxicity and ozoneforming potential (ozone contributes to photochemical smog in the atmosphere) of the vehicle exhaust.

\section{Vehicles/Fuels Tested}

Laboratory staff have tested a wide variety of original equipment manufacturer alternative fuel vehicle models, and a limited sample of aftermarket conversions. The vehicles have been tested on methanol (M85, 85\% methanol and $15 \%$ gasoline), ethanol (E85, 85\% ethanol and 15\% gasoline) compressed natural gas (CNG), propane, and reformulated gasoline (RFG).

Fuels, Vehicle Models, and Number of Vehicles Tested

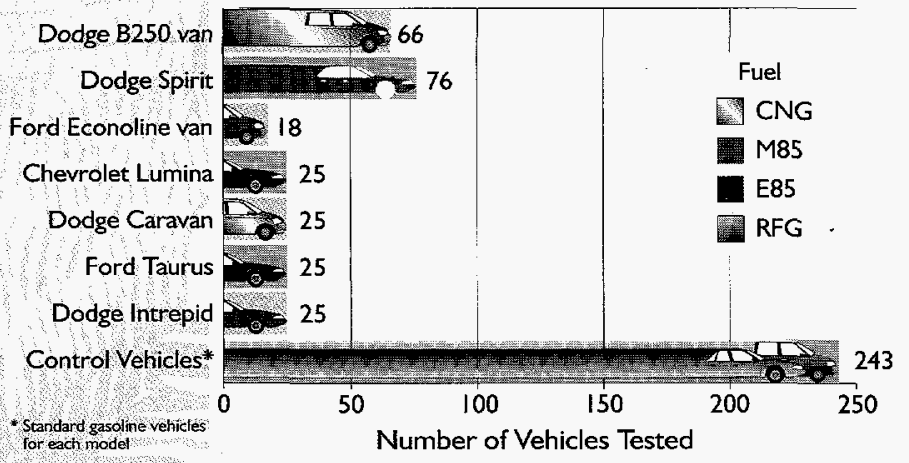

To stay current with the changing marketplace, testing of the latest qualified vehicle modifier (OVM) CNG and liquefied petroleum gas (LPG) vehicles has been scheduled.

\section{Selected Results}

When engineered and maintained properly, alternative fuel vehicles have shown the potential to significantly reduce overall emissions. Sample results from the first round of testing are shown below.

\section{Selected Early Results}

\begin{tabular}{|c|c|}
\hline Models and Fuel & $\begin{array}{l}\text { Early Exhaust Emissions Results Compared } \\
\text { to RFG }\end{array}$ \\
\hline CNG Dodge B250 van & $\begin{array}{l}30 \%-80 \% \text { reduction in } \mathrm{NO}_{x}, \mathrm{CO} \text {, and } \\
\mathrm{NMHC} .75 \% \text { reduction in ozone-forming } \\
\text { potential. }\end{array}$ \\
\hline M85 Dodge Spirit & $\begin{array}{l}\text { Modest reductions in NMHC and CO. } 40 \% \\
\text { reduction in ozone-forming potential. Small } \\
\text { increase in } \mathrm{NO}_{\mathrm{x}} \text {. }\end{array}$ \\
\hline M85 Ford Econoline van & $\begin{array}{l}\text { Modest reductions in NMHC and CO. } 50 \% \\
\text { reduction in ozone-forming potential. Small } \\
\text { increase in } \mathrm{NO}_{\mathrm{x}} \text {. }\end{array}$ \\
\hline E85 Chevrolet Lumina & $\begin{array}{l}\text { Approximately } 20 \% \text { reductions in } \mathrm{NMHC} \text {, } \\
\mathrm{CO} \text {, and } \mathrm{NO}_{\mathrm{x}} .25 \% \text { reduction in ozone- } \\
\text { forming potential. }\end{array}$ \\
\hline \multicolumn{2}{|c|}{ 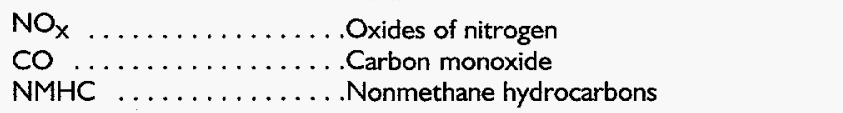 } \\
\hline $\begin{array}{l}\text { he alcohol fuels } \\
\text { ocarbon emission } \\
\text { lane. Also, the hy }\end{array}$ & $\begin{array}{l}\text { compounds such as benzene and } \\
\text { lower from the alternative fuels, } \\
\text { increased aldehyde emissions. } \\
\text { om CNG vehicles were primarily } \\
\text { carbon compounds from the }\end{array}$ \\
\hline
\end{tabular}

Hydrocarbon Emission Profile

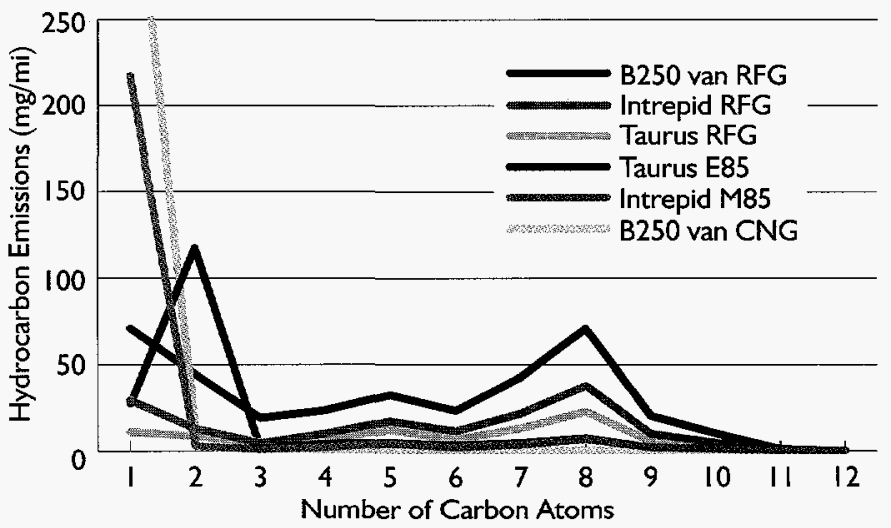

Emissions results from CNG and LPG aftermarket conversions were not as promising as the original equipment manufacturer's models. This highlights the need to consider both the fuel and the vehicle technology when evaluating options for reducing air pollution. 


\section{DISCLAIMER}

Portions of this document may be illegible in electronic image products. Images are produced from the best available original document. 


\section{Program Goal:}

To compare the in-use emissions from trucks and buses equipped with the latest certified alternative fuel engines to those from their diesel counterparts.

\section{Program Description}

To test the heavy vehicles, West Virginia University (WVU) designed and constructed a transportable chassis dynamometer with DOE funding. The ability to transport this unit from site to site allows a large number of in-use emissions tests to be conducted in cities around the country.

\section{Vehicles/Fuels Tested}

Under NREL evaluation programs, WVU has tested more than 75 alternative fuel transit buses and trucks. Vehicles were tested on ethanol (E95, or 95\% ethanol and 5\% gasoline), methanol (M100, or neat methanol), $\mathrm{CNG}$, liquefied natural gas (LNG), and biodiesel blends. At each site, closely matched diesel control vehicles were also tested for comparison. The testing has concentrated on widely used alternative fuel engine models, including the Cummins' 110 CNG engine and Detroit Diesel Corporation's $6 \mathrm{~V} 92$ alcohol engines.

\section{Description of Heavy Vehicles Tested}

\begin{tabular}{|c|c|c|c|c|}
\hline $\begin{array}{l}\text { Engine } \\
\text { Make }\end{array}$ & $\begin{array}{l}\text { Engine } \\
\text { Model }\end{array}$ & $\begin{array}{l}\text { Fuel } \\
\text { System }\end{array}$ & $\begin{array}{l}\text { Test } \\
\text { Site }\end{array}$ & $\begin{array}{l}\text { Vehicle } \\
\text { Type }\end{array}$ \\
\hline Cummins & $L 10$ & CNG & $\begin{array}{l}\text { NYC } \\
\text { Miarni, FL, } \\
\text { Tacoma, WA } \\
\text { Portland, OR } \\
\text { Sheldon, A }\end{array}$ & $\begin{array}{l}\text { Garbage Trucks } \\
\text { Buses } \\
\text { Transit Buses } \\
\text { Transit Buses } \\
\text { Transit Buses } \\
\text { Line-Haul } \\
\text { Trucks }\end{array}$ \\
\hline $\begin{array}{l}\text { Detroit } \\
\text { Diesel }\end{array}$ & Series 60 & $\begin{array}{l}\text { Methanol } \\
\text { BD20 } \\
\text { CNG } \\
\text { BD35 }\end{array}$ & $\begin{array}{l}\text { Peoria, IL } \\
\text { Minneapolis, } \\
\text { MN } \\
\text { Miami, FL } \\
\text { St. Louis, MO } \\
\text { NYC } \\
\text { Sheldon, IA }\end{array}$ & $\begin{array}{l}\text { Line-Haul } \\
\text { Trucks/Buses } \\
\text { Snowplows/ } \\
\text { Buses } \\
\text { Transit Buses } \\
\text { Transit Buses } \\
\text { Garbage Trucks } \\
\text { Line-Haul } \\
\text { Trucks }\end{array}$ \\
\hline Caterpillar & 3306 & BD35 & Sheldon, IA & $\begin{array}{l}\text { Line-Haul } \\
\text { Trucks }\end{array}$ \\
\hline
\end{tabular}

Alternative fuel heavy vehicle engine technology is evolving rapidly. Several engine manufacturers are releasing new alternative fuel models or enhanced versions of the older engines. Testing and evaluation of these latest engines is a high priority for the program.

\section{Selected Results}

Particulate matter is a serious health concern in urban areas and $\mathrm{NO}_{x}$ contributes to ozone formation in the atmosphere. In-use test results from this program have shown that alternative fuels generally have lower particulate: matter and $\mathrm{NO}_{\mathrm{X}}$ levels than their diesel counterparts. Some selected results are shown below.

Particulate Matter Emissions Results

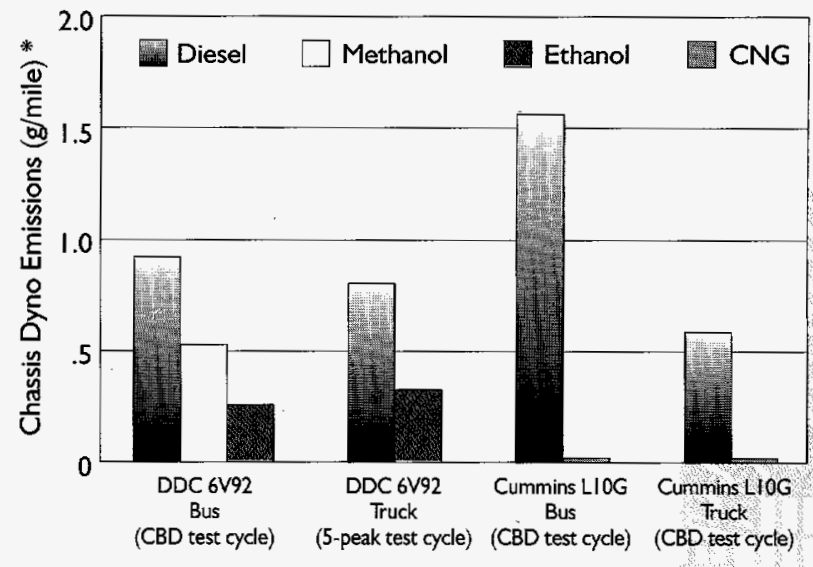

* Note: Results reported here are from chassis dynamometer testing Heavy-duty engines are certified for emissions using engine dynamometer test procedures.

\section{Emissions Testing Locations}

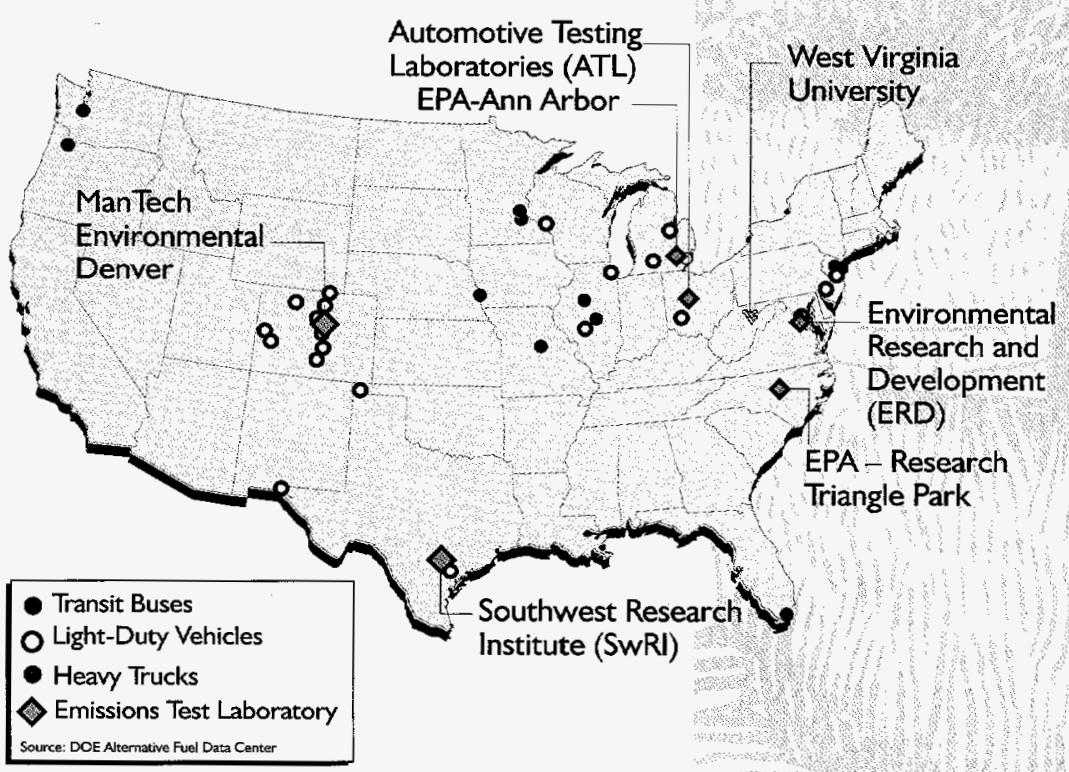




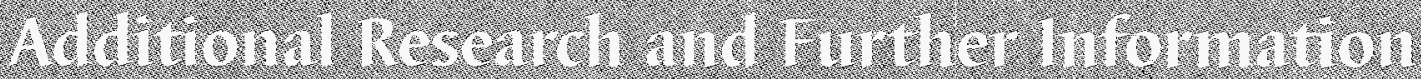

\section{NREL Research and Development (R\&D) Program}

NREL also manages an extensive alternative fuels R\&D program for DOE. This program has two main elements:

Engine optimization... research designed to increase the viability and utilization of alternative fuels by developing alternative fuel vehicle technology that is superior in performance to conventional fuel vehicles

Atmospheric reactions...research designed to increase our understanding of the potential atmospheric impacts of alternative transportation fuel use.

A number of these $R \& D$ projects involve evaluation or development of technologies for improved emissions.

\section{For More Information}

The Alternative Fuels Data Center is a mouse click or a phone call away:

Our World Wide Web site address is http://www.afdc.doe.gov

(800) 423-1DOE

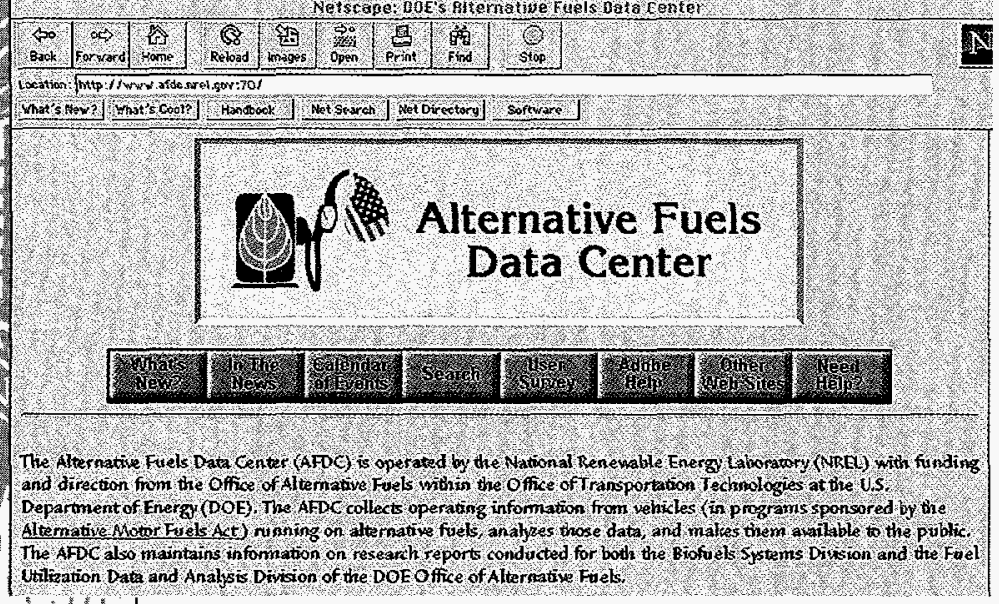

Printed with a biodegradable ink on paper containing at least $50 \%$ wastepaper, including $20 \%$ postconsumer waste

NREL/BR-425-21498

Prepared by the National Renewable Energy Laboratory for the U.S. Department of Energy's Office of Transportation Technologies
NREL maintains the center on the World Wide Web, which is accessed wore than 40,000 times per month by up to 4,000 individuals. The Web site contains a wealth of information on alternative fuel vehicle emissions: emissions data, program summaries, reports and presentations that can be downloaded, citations on related efforts, links to other sources, and much more. The center has become the nation's best-known and most comprehensive source of alternative fuels information. To talk to a human being, call (800) 423-1DOE.

\section{Selected Publications Available From NREL}

- Alternative Fuel Transit Buses: Final Results from the National Renewable Energy Laboratory Vehicle Evaluation Program, October 1996

- Compressed Natural Gas and Liquefied Petroleum Gas Conversions: The National Renewable Energy Laboratory's Experience, April 1996

- Alternative Fuel Light-Duty Vehicles: Summary of Results from the National Renewable Energy Laboratory's Vehicle Evaluation Data Collection Efforts, May 1996

- "FTP Emissions Test Results from Flexible-Fuel Methanol Dodge Spirits and Ford Econoline Vans," Society of Automotive Engineers, Inc. (SAE) paper number 961090

- "Round 1 Emissions Test Results from Compressed Natural Gas Vans and Gasoline Controls Operating in the U.S. Federal Fleet," SAE paper number 961091

- "Federal Test Procedure Emissions Test Results from Ethanol Variable-Fuel Vehicle Chevrolet Luminas," SAE paper number 961092

- Alternative Fuel Trucks Case Studies: Running Refuse Haulers on Compressed Natural Gas, and Running LineHaul Trucks on Ethanol, October 1996 


\section{DISCLAIMER}

This report was prepared as an account of work sponsored by an agency of the United States Government. Neither the United States Government nor any agency thereof, nor any of their employees, makes any warranty, express or implied, or assumes any legal liability or responsibility for the accuracy, completeness, or usefulness of any information, apparatus, product, or process disclosed, or represents that its use would not infringe privately owned rights. Reference herein to any specific commercial product, process, or service by trade name, trademark, manufacturer, or otherwise does not necessarily constitute or imply its endorsement, recommendation, or favoring by the United States Government or any agency thereof. The views and opinions of authors expressed herein do not necessarily state or reflect those of the United States Government or any agency thereof. 